\title{
本邦西部の溫泉の地球化學的研究（第二報） 山口縣の溫泉のラドン含有量
}

(昭利十シ年九月四日受領)

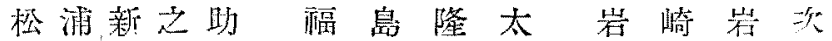

(1) 山口拲下の溫泉 18 簀所のラドン含有量を測定した。

(2) 川棚溫泉に於ては，溫泉中のラドン估地表から淺い部分に由來することが認められる。

（3）持世寺鈸鼠のラドン含有量は，これ志で報告されてるないが，相賞大で䄪 30 マッへに達ずる。

前報1に引續き山口縣下の溫泉につき行つたラドン合倠量測定の結果を報告与る。测迄した溫泉

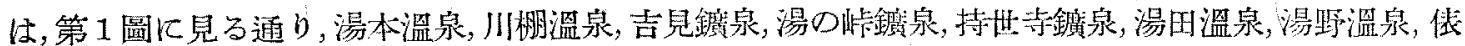

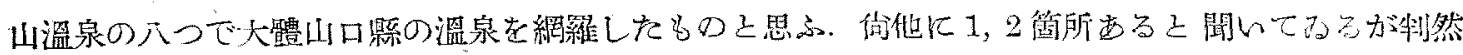
としなととはかからをい。

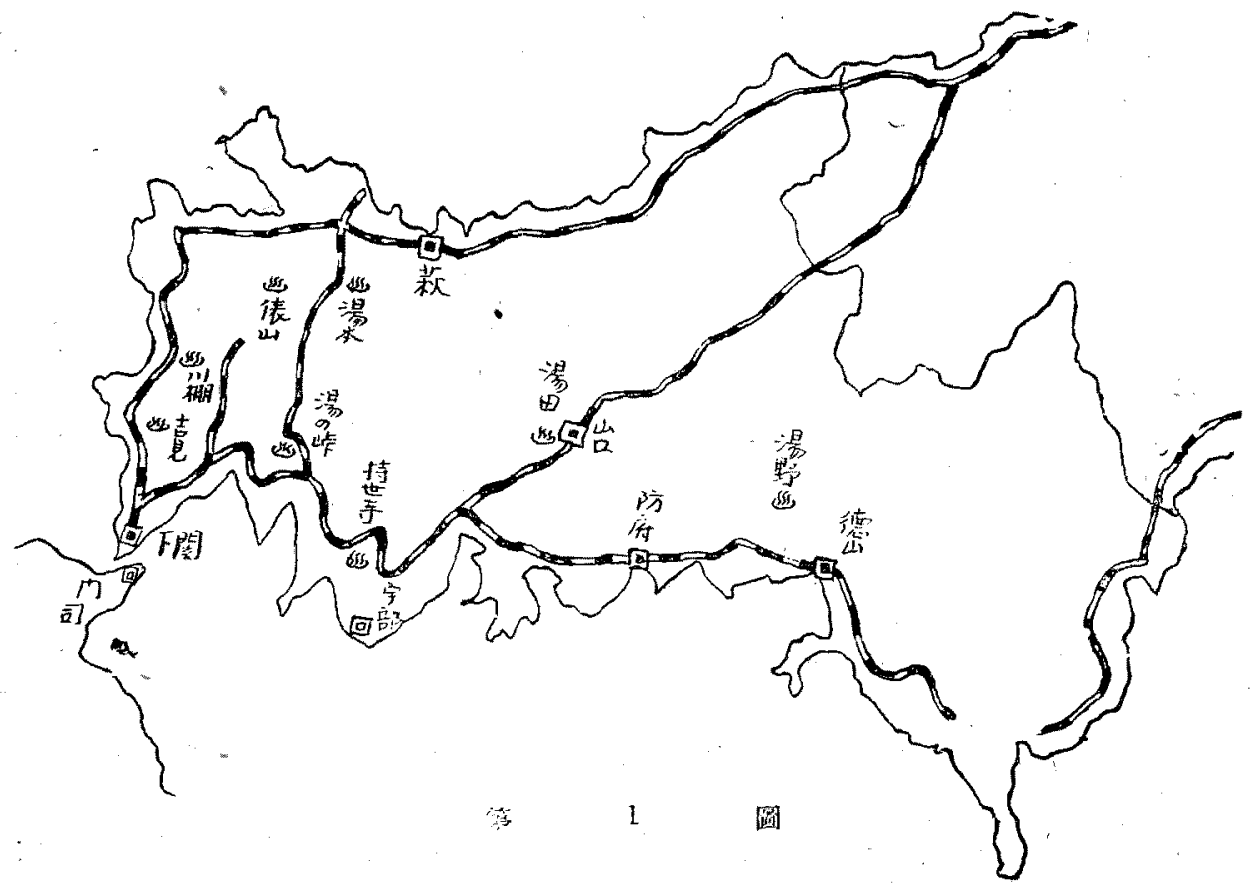

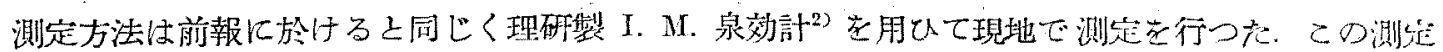

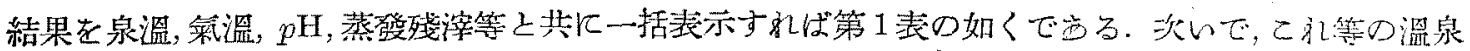
の湧出概沉々測定結果とを說明し若干の考察を試みる。

I. 湯本溫泉 (山口縣大津郡深川村) 湧出口は二つで恩湯, 澧湯の名がついてるる. 网方上も微に

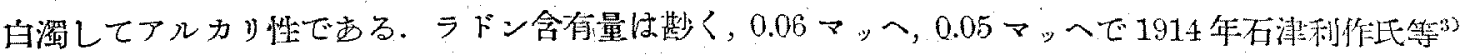

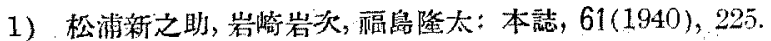

2) 飭盛里安：理研柋報, 10(1931),1105.

3) R. Ishizu: "The Mineral Springs of Japan," (1915). 
第 1 表

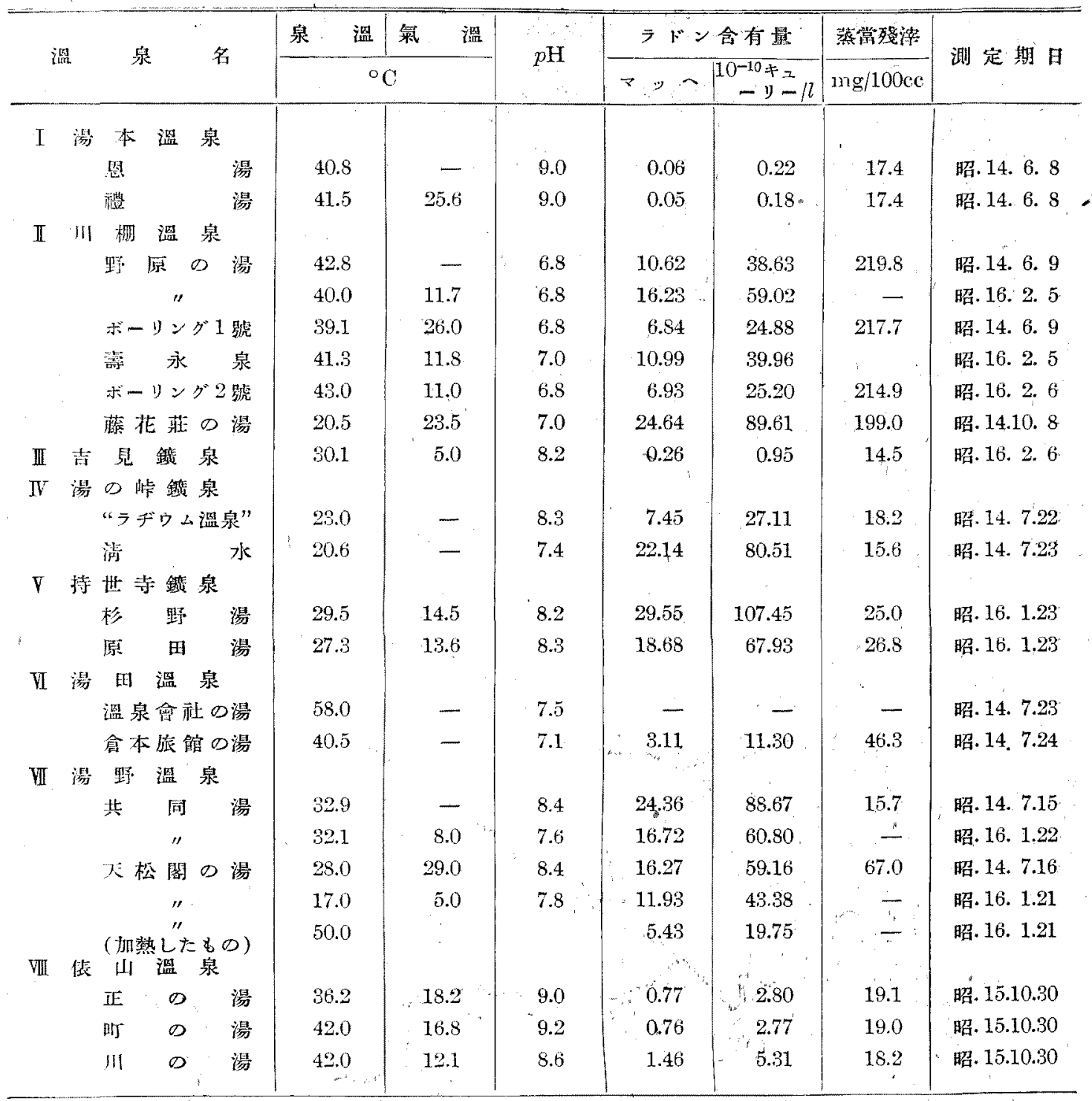

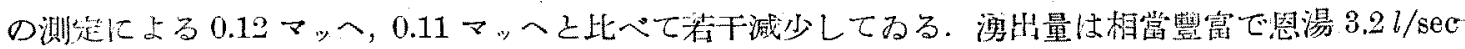
陑湯 $1.1 \mathrm{l} / \mathrm{sec}$ ですつた.

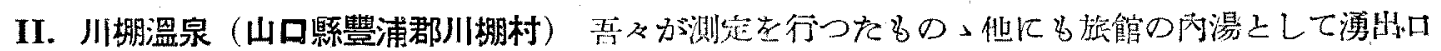

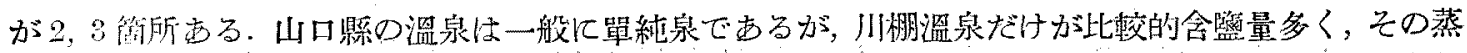
登殘语は $1 \mathrm{~g} / 6$ 超える。

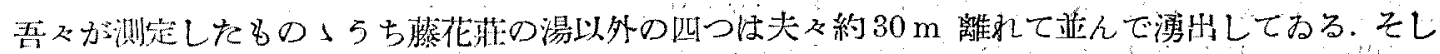

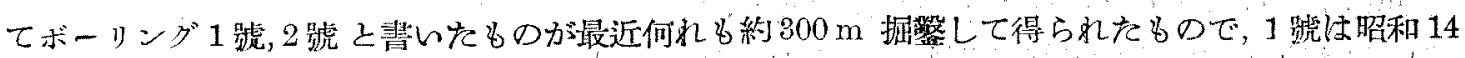

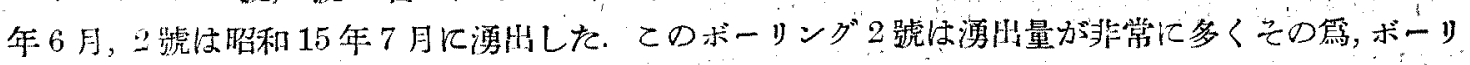

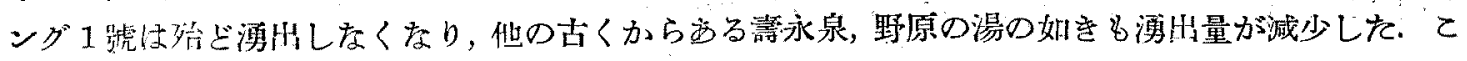

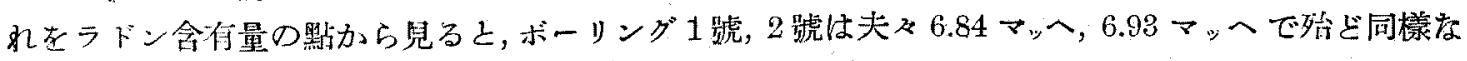

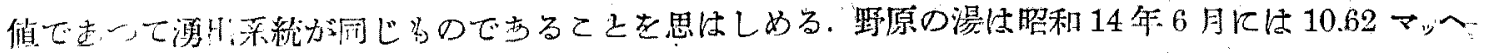




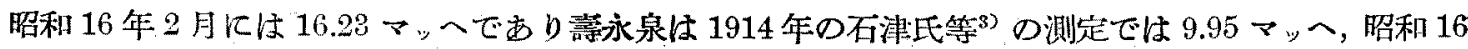
年 2 月のには 10.99 マッへで何れるボーリング 2 號涌出後には若干堆加の傾向がする. 又藤花莊內湯 上云ふのは以上の湧出口から約 $800 \mathrm{~m}$ 位離れて存在する普通の井戸であつて泉溫もずつ之低く加熱 して浴用にしてるる．ラドン含有量は $24.64 マ$ 、で著しく多い. 以上のてとから尠くとるての地方

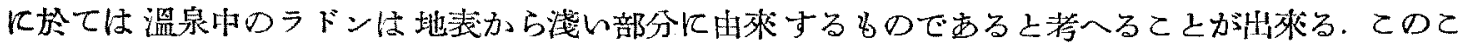

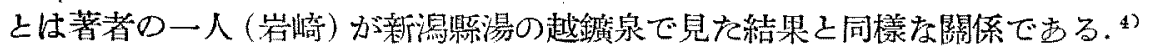

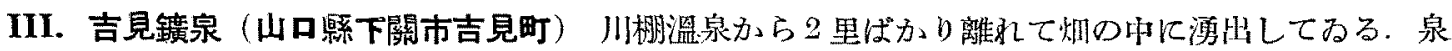
溫も低く余り利用されてみない。ラドン含有量は 0.26 マッへで尠い。

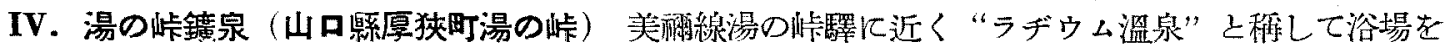

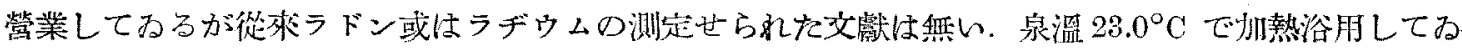

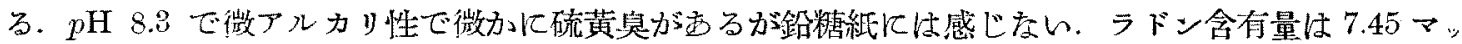
へでする.興味することはてれから $40 \mathrm{~m}$ 位踓れて满水が溥出してるる。ての漂出量は可成りに大で

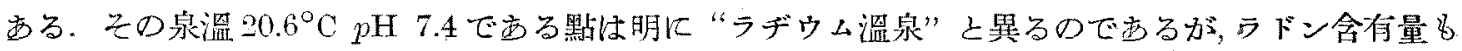
22.14マッ八で著しく大きい。

V. 持世寺鑛泉（山口縣厚陝郡厚東村持世寺）山陽線厚東等から西方約 $2 \mathrm{~km}$ 灯の山の小部落に

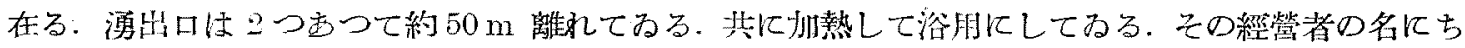

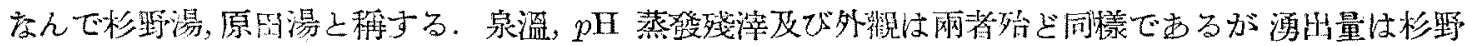

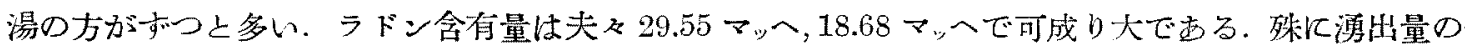

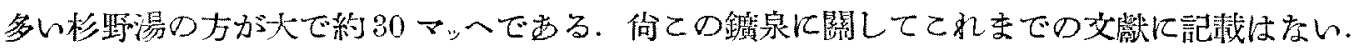

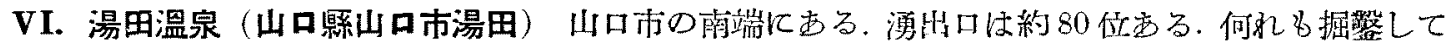
得られたもので沓潈は $40^{\circ} \mathrm{C}$ 內至 $60^{\circ} \mathrm{C}$ 位であつて $50^{\circ} \mathrm{C}$ 附近のbのが多い，何れも自然汿出せず， ポンプで吸み上げてるるので，ラドン測定のためには正猚な弑料採取を行ひ難く，吾くの目的には不 適當なので，一例として倉本旅館の內湯のラドン含有量の测走在行つたがけでする。

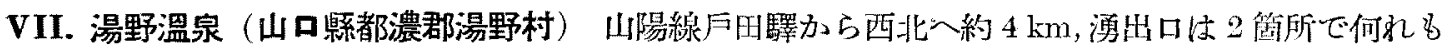

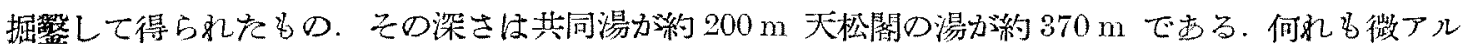
カリ性で微に硫黄棊がある，異石點は共同湯の方が泉溫少しく高く,涌出量はずつと多い．ラドン含

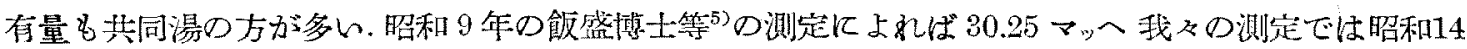
年 7 月に 24.36 マッ人昭和 16 年 1 月に 16.72 マッへで炏第に減少してみる. 又天松閏の湯も昭和 14年 7 月に 16.27 マッ, 昭和 16 年 1 月, 13.98 マッへでこ秃る減少してわる.ラドンの次第に減少してゆく 溫泉の一例になるですらう.向天松閣の湯は加熱して浴用してみるが加熱の結果ラドン含有量が如何

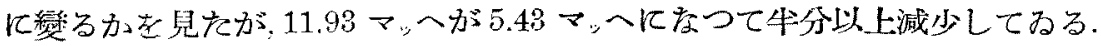

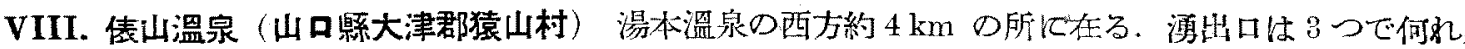

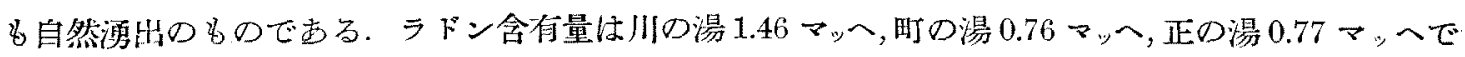
あるが 1914 年石津氏等 ${ }^{3)}$ の测定によれば川の湯 1.71 マッへ, 町の湯 0.99 マッへで若干減少してるる.

以上を綜合して,山口縣下の溫泉は泉溫の高いもの尠く川棚溫泉以外は $p \mathrm{H} 8$ 内外ですべて微つル カリ性でする.蒸發殘滓も川棚溫泉以外は $1 \mathrm{~g} / \mathrm{l}$ 以下である.ラドン含有量は一般に㙷著でする. 又同 一溫泉について異る湧出口に於ける測定值はをとへそれ等の涌出口が極めて接近してるる場合でも 既に多數に知られてるる場合の如く ${ }^{6)}$ 一般に可成りの差を示す.てれに關して, 川棚溫泉に於て掘整

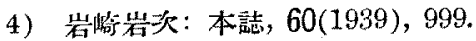

5) 飯盛里安, 畑 晋: 理研桑報, 16(1937), 1471 . 岩次：本誌，59(1938)，1024；中井敏夫：本誌，59(1938)，1184；岩嶃：本誌，60(1939)，1004.

6) 岩崎 


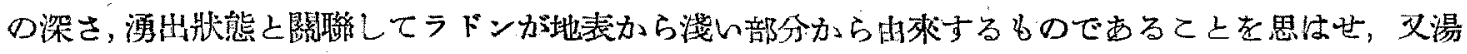

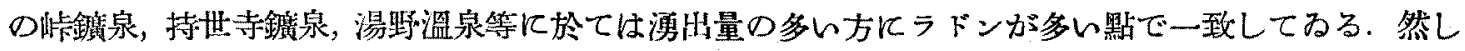

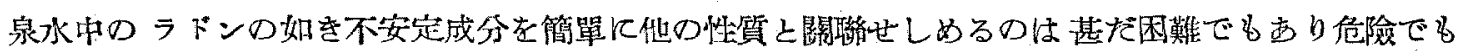
あるので, 本報では單にこれ等買泉のラドン含有量の報告に止めてそれ以上の論議は次の機會にゆづ るととにする。

(九州帝國大學理學部化學敉突) 